\title{
The strepsipteran parasite Elenchus japonicus (Strepsiptera, Elenchidae) of planthoppers consists of three genotypes
}

\author{
Yukiko Matsumoto • Masaya Matsumura • \\ Sugihiko Hoshizaki • Yuki Sato · Hiroaki Noda
}

Received: 26 April 2010/Accepted: 13 June 2011/Published online: 30 June 2011

(c) The Author(s) 2011. This article is published with open access at Springerlink.com

\begin{abstract}
The twisted-wing parasite Elenchus japonicus is a major parasitoid of rice planthoppers (Hemiptera: Delphacidae), including the brown planthopper Nilaparvata lugens, the white-backed planthopper Sogatella furcifera, and the small brown planthopper Laodelphax striatellus. Another Elenchus species, E. yasumatsui, which is considered to be synonymous with E. japonicus, has also been described in southern Asia. However, limited biological and molecular data on this important parasitoid of rice planthoppers are available. In this study, E. japonicasstylopized planthoppers were obtained from various regions in Asia and Japan. Sequences of the nuclear $18 \mathrm{~S}$ ribosomal RNA gene and the mitochondrial cytochrome oxidase I gene of the strepsipterans were analyzed from 40 samples of E. japonicus: 14 from N. lugens, 6 from $S$. furcifera and 20 from L. striatellus. Sequence analysis of these samples revealed three genotypes of E. japonicus. Of the three types of E. japonicus, one was isolated only from L. striatellus from northern Japan. The other two types were found in all three rice planthopper species collected
\end{abstract}

Electronic supplementary material The online version of this article (doi:10.1007/s13355-011-0060-z) contains supplementary material, which is available to authorized users.

Y. Matsumoto · Y. Sato · H. Noda $(\square)$

National Institute of Agrobiological Sciences,

Owashi, Tsukuba, Ibaraki 305-8634, Japan

e-mail: hnada@affrc.go.jp

\section{Matsumura}

NARO Kyushu Okinawa Agricultural Research Center,

Koshi, Kumamoto 861-1192, Japan

S. Hoshizaki

Graduate School of Agricultural and Life Sciences,

The University of Tokyo, Bunkyo, Tokyo 113-8657, Japan from a wide area in Asia. These results suggest that the three different genotypes of Elenchus can be associated with a particular geographical region and/or planthopper species. The relationship between two previously described Elenchus species and the present three genotypes needs to be elucidated.

Keywords Elenchus japonicus - Strepsiptera $\cdot$ rRNA gene $\cdot \operatorname{cox} 1 \cdot$ Planthopper

\section{Introduction}

Strepsipterans are obligate endoparasitoids that attack many insect species (Kathirithamby 2009, 2011). The morphology of the male and female strepsipterans is quite different, and the systematic position of strepsipterans is disputed (Pohl and Beutel 2008). Rice planthopper nymphs are frequently attacked by strepsipterans in the field, as well as by hymenopteran drynid wasps and mermithid nematodes. It is generally acknowledged that these nymphal and adult parasitoids are of minor importance compared with egg parasitoids in controlling field populations of economically important planthoppers (Benrey and Lamp 1994). However, ubiquitous parasitization of nymphs and adults is an important factor in the suppression of planthopper populations.

The strepsipteran parasite Elenchus japonicus (Strepsiptera, Elenchidae) was first described by Esaki and Hashimoto (1931). E. japonicus parasitizes many delphacid planthopper species, including the rice planthoppers Nilaparvata lugens (Stål) (brown planthopper, BPH), Sogatella furcifera (Horváth) (white-backed planthopper, WBPH) and Laodelphax striatellus Fallén (small brown planthopper, SBPH) (Chandra 1978, 1980; Kifune and Maeta 1986; 
Barrion and Litsinger 1987; Carcupino et al. 1998). A second Elenchus species, E. yasumatsui, was isolated from BPH and WBPH in Thailand (Kifune and Hirashima 1975), but $E$. yasumatsui is considered to be synonymous with E. japonicus (Kathirithamby 1993, 2011). Therefore, E. japonicus is the sole strepsipteran species known to attack rice planthoppers to date.

We have previously examined endosymbionts (Noda et al. 2001) and molecular markers (Matsumoto et al., unpublished observation) of rice planthoppers collected from East and Southeast Asia. During the study, stylopized planthoppers were obtained from field-collected samples. In this study, we analyzed the nuclear $18 \mathrm{~S}$ ribosomal RNA (rRNA) gene and mitochondrial cytochrome oxidase I (coxl) gene sequences of E. japonicus to elucidate any intraspecies variation. The obtained nucleotide sequences revealed the existence of at least three Elenchus genotypes that attack rice planthoppers.

\section{Materials and methods}

\section{Insect samples}

Eighteen strepsipteran individuals were dissected from 17 planthoppers: 17 from 16 L. striatellus (SBPH) hosts collected from the northern region of Japan, which were used in a previous study (Noda et al. 2001), and 1 from $1 \mathrm{~N}$. lugens (BPH) host collected from Fujian, China (Table 1). Three species of rice planthoppers, N. lugens, S. furcifera and L. striatellus, were collected from Japan and other Asian countries (Table 1; Supplementary Table 1). Some planthopper populations were reared in the laboratory, using rice seedlings for one or two generations after collection. The samples were preserved in a freezer or in absolute ethanol until use.

DNA purification, polymerase chain reaction (PCR) and sequencing

PCR templates for PCR were prepared from dissected Elenchus samples in planthopper hosts or directly from planthopper samples parasitized with Elenchus. Some samples were homogenized with $30-50 \mu \mathrm{l}$ of STE [100 mM NaCl, $1 \mathrm{mM}$ EDTA (pH 8.0) and $10 \mathrm{mM}$ Tris$\mathrm{HCl}(\mathrm{pH}$ 8.0)] buffer and digested with proteinase $\mathrm{K}$. In the other samples, DNA was purified using the DNeasy blood and tissue kit (Qiagen Inc, Valencia, CA).

The nuclear 18S rRNA gene of Elenchus was first amplified using primers for the internal transcribed spacer (ITS), namely, ITS5 (5'-GGAAGTAAAAGTCGTAACAA GG-3') (White et al. 1990) and Strep_5.8A_r (5'-GAT TGTTAATTATAAAATGTTAACAATCTG-3') designed from the sequence of Stylops melittae (accession number Y14454). In the second PCR, the region of the 18S rRNA gene was amplified using the general primers of White et al. (1990). After preliminary sequencing of the rRNA gene, a pair of primers for amplification of the $3^{\prime}$ region of the $18 \mathrm{~S}$ rRNA gene and the ITS 1 of the rRNA gene from various samples was designed: S_18S_f1 (5'-AGGAGCAATAAC AGGTCTGTGA-3') and S_ITS1_rl (5'-TTTTGGCGAAA ATCCTTATGACCTT- $3^{\prime}$ ).

The mitochondrial coxl gene sequence was first amplified using C1-J-1751 (5'-GGATCACCTGATATAG CATTCCC- $\left.3^{\prime}\right)$ and C1-N-2191 (5'-CCCGGTAAAATT AAAATATAAACTTC-3') (Simon et al. 1994), and the preliminary sequences were determined. A pair of primers was then designed: S_cox1_f $\left(5^{\prime}\right.$-TTYAGATTTTGAR TTTTAATMCCATCT-3') and S_cox1_r (5'-GATGAATT AAAATTTCGATCAAATA-3') for Elenchus samples.

The basic PCR reaction mixture $(20 \mu \mathrm{l})$ consisted of $0.15 \mu \mathrm{M}$ deoxynucleotides, $0.5 \mu \mathrm{M}$ forward primer, $0.5 \mu \mathrm{M}$ reverse primer, $1 \mu \mathrm{l}$ of the PCR template and $0.5 \mathrm{U}$ of Taq DNA polymerase (Takara Bio Inc., Tokyo, Japan) in PCR buffer (Takara Bio Inc.). The PCR temperature profile was $94^{\circ} \mathrm{C}$ for $2 \mathrm{~min}$, followed by $94^{\circ} \mathrm{C}$ for $30 \mathrm{~s}$, $52^{\circ} \mathrm{C}$ for $30 \mathrm{~s}$ and $72^{\circ} \mathrm{C}$ for $45 \mathrm{~s}$ for $30-35$ cycles, with a final extension at $72^{\circ} \mathrm{C}$ for $5 \mathrm{~min}$. Electrophoresis in $1 \%$ $(\mathrm{w} / \mathrm{v})$ agarose/TAE gel was performed to confirm the PCR-amplified products.

The amplified DNA from the 18S rRNA gene was purified using Sephacryl S-300 HR (Amersham Pharmacia Biotech Inc., Uppsala, Sweden) spin columns and cloned into the pGEM-T vector (Promega Corp., Madison, WI). The ligated vector was introduced into Escherichia coli $\mathrm{DH}$ 5 alpha (Toyobo Co. Ltd., Tokyo, Japan), and the inserted DNA fragments were amplified using M13-20 and reverse primers directly from the positive white colonies by using PCR. The PCR temperature profile was $90^{\circ} \mathrm{C}$ for $10 \mathrm{~min}$, followed by $94^{\circ} \mathrm{C}$ for $30 \mathrm{~s}, 56^{\circ} \mathrm{C}$ for $30 \mathrm{~s}$ and $72^{\circ} \mathrm{C}$ for 1-2 min for $30-35$ cycles, and a final extension at $72^{\circ} \mathrm{C}$ for 5 min. The amplified fragments were purified using Sephacryl S-300 HR spin columns, and 4-6 clones were used for sequencing. For mitochondrial DNA, amplified DNA was directly sequenced using the primers S_cox1_f and S_cox1_r. The sequencing reactions were performed with the amplified DNA using a sequencing kit (ABI PRISM Dye Primer Cycle Sequencing Kits; Applied Biosystems Division, Perkin-Elmer Inc.); the reaction products were sequenced using a DNA Sequence Analyzer (model 3730; Applied Biosystems).

Phylogenetic analysis

The nucleotide sequences of the 18S rRNA gene (NCBI accession no. AB519811-519814) and the mitochondrial 
Table 1 Sampling sites of planthoppers and sequence types of their Elenchus parasites

\begin{tabular}{|c|c|c|c|c|c|c|}
\hline & \multirow[t]{2}{*}{ Location } & \multirow[t]{2}{*}{ Collection date } & \multicolumn{3}{|c|}{ Number of hosts } & \multirow{2}{*}{$\begin{array}{l}\text { Elenchus type } \\
\text { (number) }\end{array}$} \\
\hline & & & $\mathrm{B}$ & $\mathrm{W}$ & $\mathrm{S}$ & \\
\hline \multicolumn{7}{|c|}{ Isolated Elenchus } \\
\hline \multirow[t]{5}{*}{ Japan } & Furukawa, Fukushima & 1996 & & & 2 & TG (2) \\
\hline & Gohyakugawa, Fukushima & 1996 & & & 2 & TG (2) \\
\hline & Natori, Miyagi & 1996 & & & 1 & TG (1) \\
\hline & Furukawa, Fukushima & 1997 & & & $11^{\mathrm{a}}$ & TG (10) \\
\hline & & & & & & $\mathrm{AC}(2)$ \\
\hline China & Fuqing, Fujian & September 2006 & 1 & & & TA (1) \\
\hline \multicolumn{7}{|c|}{ Stylopized planthoppers } \\
\hline \multirow[t]{4}{*}{ Japan } & Ureshino, Saga & June 15, 2006 & & 1 & & $\mathrm{AC}(1)$ \\
\hline & Kawazoe, Saga & June 15, 2006 & & 1 & & $\mathrm{AC}(1)$ \\
\hline & Koshi, Kumamoto & June 16, 2005 & 2 & & & $\mathrm{AC}(2)$ \\
\hline & Koshi, Kumamoto & June 26, 2006 & & 1 & & TA (1) \\
\hline \multirow[t]{3}{*}{ Taiwan } & Daya, Taichung & November 9, 2005 & 1 & & & TA (1) \\
\hline & Jiouru, Pingtung & October 18,2008 & & & 1 & TA (1) \\
\hline & Chihshang, Taitung & November 5, 2008 & & & 2 & $\mathrm{AC}(2)$ \\
\hline \multirow[t]{3}{*}{ China } & Fuqing, Fujian ${ }^{\mathrm{b}}$ & September 2006 & 2 & & & TA (2) \\
\hline & & & & 1 & & $\mathrm{AC}(1)$ \\
\hline & Shantou, Guangdong ${ }^{\mathrm{b}}$ & September 2006 & & 2 & & $\mathrm{AC}(2)$ \\
\hline \multirow[t]{4}{*}{ Vietnam } & Long Dinh, Tien Giang ${ }^{\mathrm{b}}$ & September 3, 2006 & 1 & & & TA (1) \\
\hline & Hoa Ninh, Tien Giang ${ }^{\mathrm{b}}$ & September 4, 2006 & 1 & & & TA (1) \\
\hline & SOFRI $^{\mathrm{c}}$ & November 26, 2007 & 5 & & & TA (5) \\
\hline & SOFRI $^{\mathrm{c}}$ & May 17, 2008 & 1 & & & TA (1) \\
\hline
\end{tabular}

Hosts B, W and S indicate the brown planthopper, the white-backed planthopper and the small brown planthopper, respectively

a Two types of strepsiptera parasites (TG and AC) were present in one small brown planthopper host

${ }^{\mathrm{b}}$ Individual planthoppers were sampled after reared for one generation in the laboratory

c Southern Fruit Research Institute in Vietnam

coxl gene sequences (AB519815-519817, AB571810571823) were deposited in the DNA databanks. Phylogenetic analyses were performed using the above sequences and NCBI-deposited data from Mengenilla chobauti (AF423800), Caenocholax fenyesi texensis (DQ026302), Crawfordia sp. (U65163), Xenos pecki (U65164), Triozocera mexicana (U65159), Caenocholax fenyesi (U65160), Xenos vesparum (X77784) and Stylops melittae (X89440) for the 18S rRNA gene and three Myrmecolachid spp., two C. fenyesi, E. japonicus (AY039094-AY039099) and $X$. vesparum (DQ364229) for the coxl gene. These nucleotide sequences were aligned using Clustal X (Thompson et al. 1997). Maximum parsimony (MP) analysis was conducted using PAUP* 4.0b10 (Swofford 2002), based on a heuristic search with stepwise addition of 100 random replications using tree-bisection-reconnection. Bootstrap supports of branches were calculated for 1,000 replicates.

\section{Results}

18S rRNA and ITS1 sequences in Elenchus

Partial sequences of the nuclear rRNA gene, namely, the 18S rRNA-ITS1 sequence (ca. 590-720 bp), were determined for all 18 dissected strepsipteran individuals (Table 1, isolated Elenchus). This region included $381 \mathrm{bp}$ of the $3^{\prime}$ region of the 18S rRNA gene. The sequence boundaries between the 18S rRNA gene and ITS1 were predicted on the basis of the corresponding sequence in Drosophila melanogaster (NCBI accession number M21017). The ITS1 region was varied in size and sequence, whereas the sequence of the $3^{\prime}$ region of the $18 \mathrm{~S}$ rRNA gene was conserved with the same length. Only three different sites were present in the sequences of the $3^{\prime}$ region of the 18S rRNA gene, thereby resulting in three major sequence types. The varied nucleotide region, 
including three varied nucleotide sites, was observed at 324-328 bp upstream from the 18S rRNA-ITS1 boundary; the three sequence types were $5^{\prime}$-TAATG- $3^{\prime}, 5^{\prime}$-AAAAC$3^{\prime}$ and $5^{\prime}$-TAATA- $3^{\prime}$. The three types were designated as TG, AC and TA, respectively, based on the last two nucleotides (Supplementary Fig. 1; NCBI accession nos. TG, TA_a, TA_b and AC type as AB519811, AB519812, AB519813 and AB 519814, respectively; two types of TA were found, as described below). The three types in the 18S rRNA gene sequence were accompanied by a sequence size variation in the ITS1 region. The three different representative lengths of the partial ITS1 sequence for the TG, AC and TA types were 333, 328 and $211 \mathrm{bp \text {, }}$ respectively.

The TG and AC types were detected in Elenchus from SBPH, whereas the TA type was detected in Elenchus from BPH (Table 1). Among the 18 samples, 15, 2 and 1 showed the TG, AC and TA type, respectively. The sequences of the $3^{\prime}$ region of the $18 \mathrm{~S}$ rRNA gene $(381 \mathrm{bp})$ of the 15 samples with the TG type were identical. As described below, E. japonicus with the TA and AC types were additionally obtained from the stylopized planthopper samples collected during 2005-2008. The $3^{\prime}$ region sequences of the 18S rRNA gene from a total of 14 samples with the TA type and 11 samples with the AC type were identical. Respective strepsipterans possessed one of the sequence types, namely, TG, AC or TA; 4-6 clones from each sample showed identical sequence types.

We designed a specific primer pair for detecting the three types of Elenchus sequences. The primers S_18S_f1 and S_ITS1_r1 specifically amplified a single band from the 18S rRNA gene of Elenchus; no PCR bands were amplified from non-stylopized BPH, WBPH or SBPH (data not shown). Therefore, the primers could detect the Elenchus parasites in their hosts without dissecting them. Preliminary PCR detection was performed for the planthopper samples collected from various regions in Asia. Since strepsipterans were not detected in planthopper populations reared in the laboratory for more than one generation, stylopized frequencies were calculated on the basis of the samples collected in the field and the samples reared for one generation in the laboratory. Positive stylopizing rates varied among populations, 0-90\% (38/347 individuals of 19 populations) for $\mathrm{BPH}, 0-50 \%$ ( $16 / 134$ of 12 populations) for WBPH and $0-13.3 \%$ (4/120 of 8 populations) for SBPH (Supplementary Table 1).

Mitochondrial coxl sequences in three genotypes of Elenchus

Partial mitochondrial coxl sequences ( 295 bp) were determined in the 18 Elenchus samples and in another 22 planthopper samples that were PCR-positive for strepsipterans
(Table 1). The PCR primers $S_{-}$cox1_f and $S_{-}$cox $1 \_r$ amplified the Elenchus coxl gene but did not amplify the host planthopper genes (data not shown). Insertions and deletions were not observed in Elenchus coxl sequences. Mitochondrial nucleotide sequences were also divided into three types, namely, $\mathrm{mt} 1, \mathrm{mt} 2$ and $\mathrm{mt} 3$, which corresponded to the TG, TA and AC types, respectively, in the 18S rRNA gene (NCBI accession nos. representative $\mathrm{mt} 1, \mathrm{mt} 2$ and $\mathrm{mt} 3$ type as AB519815, AB519816 and AB519817, respectively) (Supplementary Fig. 2). Each respective planthopper sample showed one of the 18S rRNA sequence types and coxl types. Although some nucleotide polymorphisms were detected in TG/mt1 (AB571810-AB571819) and AC/mt3 (AB571820-AB571823), the nucleotide substitutions were mostly synonymous. Intra-genotype homogeneity was 95.9\% (283/295 nucleotides) and 98.6\% (291/295 nucleotides) for the $\mathrm{TG} / \mathrm{mt} 1$ and $\mathrm{AC} / \mathrm{mt} 3$ types, respectively. All were identical in the $\mathrm{mt} 2$ genotype. Only one non-synonym polymorphism [ATT (Val) $\rightarrow$ GTT (Ile), in the 112th-114th nucleotides of $295 \mathrm{bp}$ ] was detected in one individual sequence of the mt1 type, from a sample collected in Furukawa, Fukushima in 1997 (AB571816). The nucleotide sequence substitution rates in $295 \mathrm{bp}$ using each representative sequence was $12.2 \%$ between the TG/mt 1 and $\mathrm{TA} / \mathrm{mt} 2$ type, $20.3 \%$ between the TG/mt 1 and $\mathrm{AC} / \mathrm{mt} 3$ type, and $20.0 \%$ between the $\mathrm{TA} / \mathrm{mt} 2$ and $\mathrm{AC} / \mathrm{mt} 3$ type. The amino acid (aa) sequence substitution rates in 98 aa was $10.2 \%$ between the $\mathrm{TG} / \mathrm{mt} 1$ and $\mathrm{TA} / \mathrm{mt} 2$ type, $15.3 \%$ between the $\mathrm{TG} / \mathrm{mt} 1$ and $\mathrm{AC} / \mathrm{mt} 3$ type and $16.3 \%$ between the $\mathrm{TA} / \mathrm{mt} 2$ and $\mathrm{AC} / \mathrm{mt} 3$ type.

\section{Geographic distribution of Elenchus types}

The TG/mt1 type, detected in SBPH from northern Japan, was not found in the planthopper populations from the overseas countries or western Japan collected during 2005-2008 (Table 1; Fig. 1). The AC/mt3 type, detected in SBPH from Furukawa, was present in BPH and WBPH collected from western Japan, in WBPH from Fujian and Guangdong, China, and in SBPH from Taitung, Taiwan. The TA/mt2 type, detected in BPH from Fujian, China, was detected in BPH from Taiwan, China and Vietnam, WBPH from western Japan and SBPH from Taitung, Taiwan (Table 1).

\section{S rRNA heterogeneity of the TA types}

Sequences of the upstream $5^{\prime}$ region of the three representative 18S rRNA genes were further determined, because strepsipterans have an unusually long nucleus $18 \mathrm{~S}$ rRNA gene in the genome (Chalwatzis et al. 1995). The sequences of the $5^{\prime}$ region of the $18 \mathrm{~S}$ rRNA gene varied 


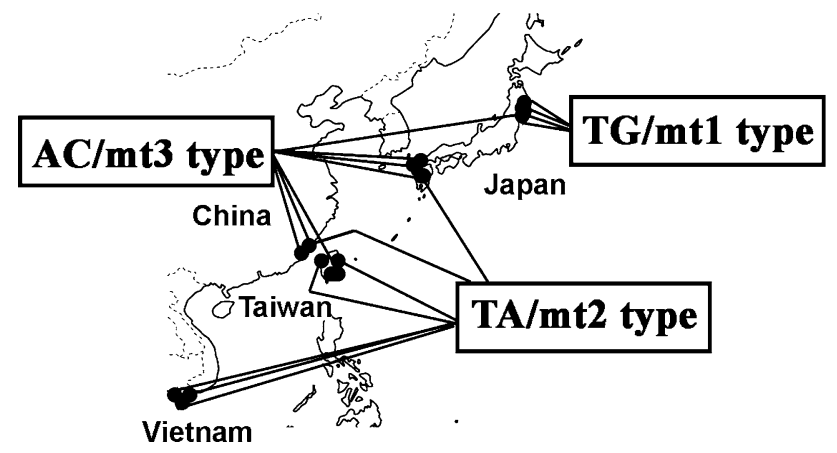

Fig. 1 Sampling sites and genotypes of Elenchus species

among the three types, and the TA type had two variations, TA_a and TA_b. The representative length of the 18S rRNA gene, namely, 2,970, 2,909, 2,694 and 2,965 bp, was determined for the TG, TA_a, TA_b and AC type, respectively (AB519811, AB519812, AB519813 and AB519814, respectively). These 18S rRNA gene sequences included highly conserved regions and varied regions with some deletions or insertions (Supplementary Fig. 1). Each of the four Elenchus samples examined, i.e., two from BPH (Fujian, China and Taichung, Taiwan), one from WBPH (Koshi, Kumamoto) and one from SBPH (Pingtung, Taiwan), possessed both TA types, thereby suggesting that individual strepsipterans possess $18 \mathrm{~S}$ rRNA gene copies of the different TA sequences. The incidence of the TA_b type ranged from $25 \%$ ( $1 / 4$ clones) to $62.5 \%$ ( $5 / 8$ clones). The difference between TA_a and TA_b types was mainly the presence or absence of the three main regions, namely, 63, 44 and 86 bp (Supplementary Fig. 1).

Phylogenetic analyses

Phylogenetic analyses were performed to elucidate the relationship among the three observed E. japonicus types and between other strepsipteran species, including those deposited in NCBI. An MP unrooted tree was constructed with PAUP* 4.0b10. A sequence length of $1,023 \mathrm{bp}$ including a 6-nucleotide gap was obtained by multiple alignment based on the sequences of Elenchus 18S rRNA genes (2,694-2,970 bp) and NCBI-deposited strepsipteran sequences. The number of parsimony informative characters was 178, and the tree length, consistency index (CI) and retention index (RI) were 438, 0.740 and 0.734 , respectively. The TG, TA_a, TA_b and AC types of E. japonicus formed one clade with a strong supporting bootstrap value of 100\%; moreover, E. japonicus, Crawfordia sp., Xenos vesparum, X. pecki and Stylops melittae clustered together with a supporting bootstrap value of $79 \%$ (Fig. 2a).

On the basis of the sequence length of $273 \mathrm{bp}$, including a 6-nucleotide gap, after alignment of the coxl
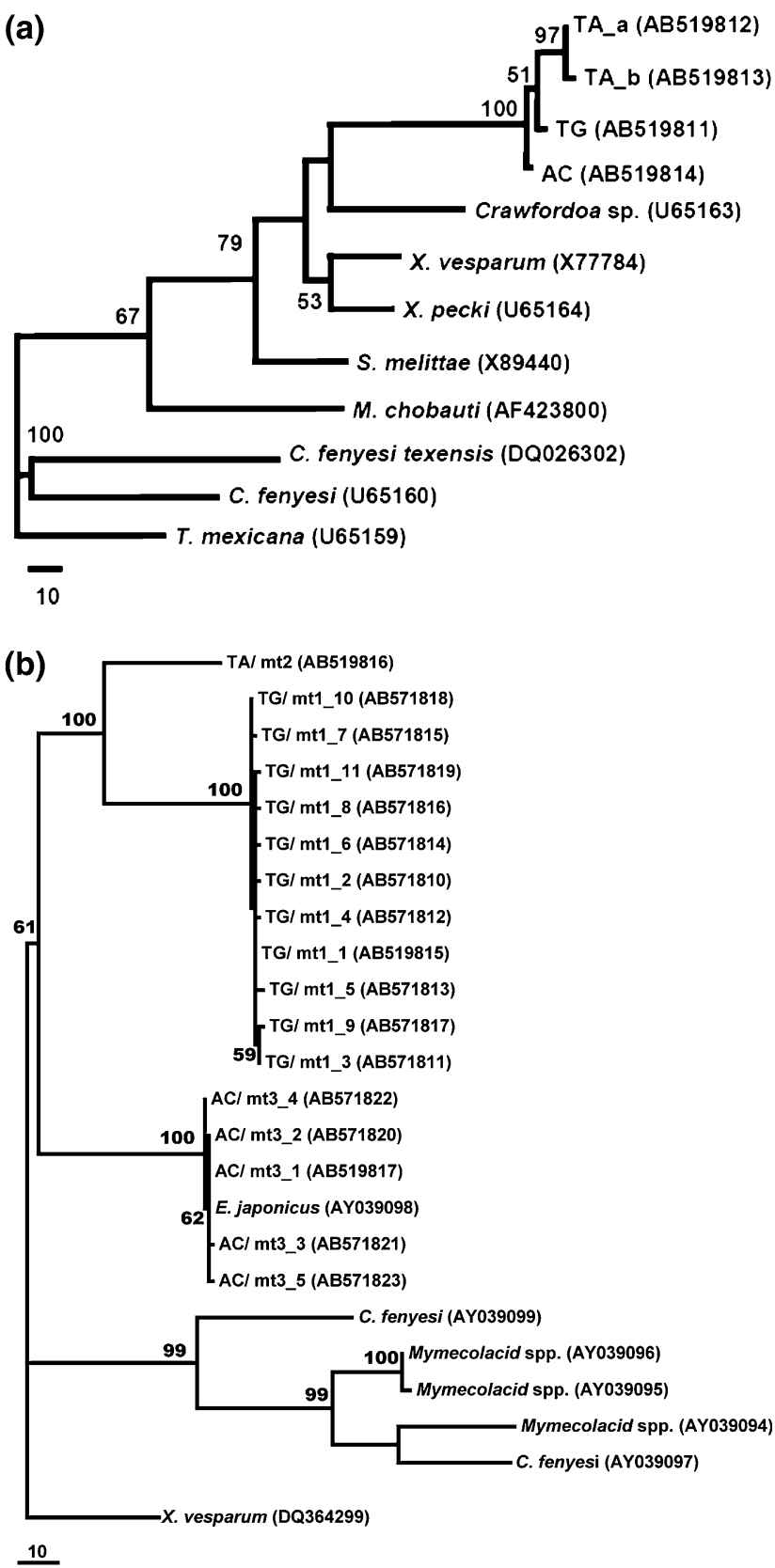

Fig. 2 Maximum parsimony trees based on partial 18S rRNA genes (a) and cox 1 genes (b). Bootstrap values of $>50 \%$ are indicated

gene sequences of the present study and NCBI-deposited data, 140 parsimony informative characters were observed and the tree length, CI and RI was 356, 0.714 and 0.848 , respectively. Figure $2 \mathrm{~b}$ suggests a monophyletic group of Elenchus coxl gene sequences (61\%). Eleven coxl sequences belonging to the TG type formed 1 clade with a $100 \%$ bootstrap value, and 5 coxl sequences of the AC type and 1 from E. japonicus (AY039098) formed a monophyletic group with a $100 \%$ bootstrap value. 


\section{Discussion}

\section{Nuclear 18S rRNA sequence}

The rRNA sequences were determined from 40 Elenchus samples; 15 sequences belonged to the TG type, 14 to the TA type and 11 to the AC type. Some nucleotide polymorphisms were present in the ITS1 region within these types. Within the TA type, two subtypes (TA_a and TA_b) were found; the two TA subtypes were intra-individual variations among copies of the rRNA gene. An unusually long sequence of the 18S rRNA gene has been reported in strepsipteran species, which shows an odd secondary structure (Chalwatzis et al. 1995; Choe et al. 1999; Gillespie et al. 2005). In our study, E. japonicus also had a long 18S rRNA gene.

Alignment of the TA type with other strepsipteran sequences showed that the three insertion/deletion regions were predicted to be inside the $18 \mathrm{~S}$ rRNA secondary structure $\mathrm{V} \mathrm{4}$, in which strepsipteran-specific helices are formed by long insertions (Choe et al. 1999; Gillespie et al. 2005). Although the rRNA gene belongs to a multigene family consisting of many copies, the concerted evolutional system has promoted its homogeneity (Dover 1982; Tautz et al. 1988). However, intra-individual polymorphisms were present in the Elenchus TA genotype. The function of the long 18S rRNA and the significance of the heterogeneity of the TA type are unclear. The 18S rRNA genes of strepsipterans are of interest not only because of their structural uniqueness, but also because of the evolution of this insect group.

\section{Three genotypes in E. japonicus}

Based on rRNA and mitochondrial gene sequence data, three different genetic types of Elenchus species were found to stylopize rice planthoppers. The previously reported 18S rRNA gene sequence of E. japonicus (accession no. U65162; Whiting et al. 1997) belonged to the AC type, and the coxl gene sequence of E. japonicus (AY039098; Halbert et al. 2001) was identical to that of the AC/mt3 type in the present study (Supplementary Fig. 2). Phylogenetic trees indicate a monophyletic origin of the three genotypes. However, these three genotypes seem to be isolated or possess a certain barrier for gene flow among the genotypes, because three distinct genotypes were clearly identifiable based on the 18S rRNA and coxl genes. The nucleotide sequence difference (12.2-20.3\%) and aa sequence difference (10.2-16.3\%) among the three mitochondrial genotypes were extremely high. No apparent genetic cross was found among the three genetic types obtained from 40 samples, as far as the nuclear 18S rRNA gene and mitochondrial coxl gene are concerned, although some of the samples were sympatrically collected. Moreover, our findings indicate that host preference may have developed among the genotypes. The TG/mt1 genotype of E. japonicus was found only in SBPH. The TA/mt2 genotype was mostly (12/14) found in BPH, with only one case each in $\mathrm{WBPH}$ and $\mathrm{SBPH}$ specimens. The $\mathrm{AC} / \mathrm{mt} 3$ genotype was found in two $\mathrm{BPH}$, five $\mathrm{WBPH}$ and four SBPH samples. These findings suggest that the three groups represent independent species. It is important to examine whether certain morphological differences are present among the three genotypes of Elenchus.

Two Elenchus species, E. japonicus and E. yasumatsui, have been reported, although E. yasumatsui is considered to be synonymous with E. japonicus (Kathirithamby 1993, 2011). Both E. japonicus and E. yasumatsui are reported to parasitize BPH, WBPH and other Delphacidae; however, E. japonicus is considered to prefer WBPH as a host (Barrion and Litsinger 1987; Kitamura and Nishikata 1987; Maeta et al. 2007), whereas E. yasumatsui prefers BPH (Chandra 1980). E. japonicus parasitization has been reported in Japan, the Philippines (Barrion and Litsinger 1987; Yano and Kifune 1994) and on the East China Sea (Kifune and Maeta 1986; Kifune 1986; Kitamura and Nishikata 1987; Halbert et al. 2001; Maeta et al. 2007). In contrast, E. yasumatsui parasitization has been described only in southern Asia (Kifune and Hirashima 1975; Chandra 1978; Hirashima et al. 1979; Chandra 1980; Barrion and Litsinger 1987). The present results seem to indicate that $E$. yasumatsui may indeed be a different species from E. japonicus, but that one of the genotypes of E. japonicas, plausibly the TA/mt2 type, may be related to E. yasumatsui.

It is possible that at least one E. japonicus genotype, the $\mathrm{TG} / \mathrm{mt} 1$ type, is associated with its geographic region. Rice planthoppers are long-distance migratory species. BPH and WBPH cannot overwinter in northeastern Asian countries, including Japan, Korea and Northern China, and annually migrate there from lower latitude regions in May, June and July (Kisimoto 1976; Hirao and Ito 1980). WBPHs stylopized by E. japonicus were captured in the East China Sea (Noda 1986; Kifune and Maeta 1986), which indicates that Elenchus also migrates for long distances with the host planthopper every year. On the other hand, SBPH overwinters in northeastern Asian countries including Japan and also migrates there from Mainland China, as do WBPH and BPH (Otuka et al. 2010). In particular, the geographic pattern of mitochondrial DNA diversity in Elenchus should be strongly influenced by the migration of rice planthoppers, because strepsipteran adult females do not leave the host and cannot disperse without the dispersal of their host. In our study, the $\mathrm{TA} / \mathrm{mt} 2$ and $\mathrm{AC} / \mathrm{mt} 3$ types of E. japonicus were widely detected in Asia, and, therefore, these parasites seem to extend their geographic distribution with the 
aid of the migration of host planthoppers every year. In contrast, the Elenchus TG/mt1 type was only found in the northern Japanese population of SBPH. Therefore, it is possible that the TG/mt1 genotype of E. japonicus is historically associated with the Japanese overwintering populations of SBPH. It is important to elucidate the geographic movement of E. japonicus within planthopper migrants.

Elenchus has been reported to parasitize other planthopper species, including Nilaparvata bakeri (Barrion and Litsinger 1987), N. muiri (Kifune 1986), Sogatella longifurcifera, S. panicola (Kifune and Maeta 1986), S. kolophon and S. pusanus (Barrion and Litsinger 1987). These planthopper species are also surely involved in the distribution and movement of Elenchus, even though some of these species are not long-distance migrants.

Acknowledgments Planthopper samples were kindly provided by or collected with the assistance of Katsuya Ichinose of the Japan International Research Center for Agricultural Sciences, Japan, Ho Van Chien of the Southern Regional Plant Protection Center, Vietnam, Dinh Van Thanh of the Plant Protection Research Institute, Vietnam, Jian-Qiang Wang and Jin-Long Huang of the Ministry of Agriculture, China, Shou-Horng Huang and Yi-Shin Chien of the Chiayi Agricultural Experiment Station, Taiwan, Ta-Chi Yang of the Hualien District Agricultural Research and Extension Station, Taiwan, and Fumitaka Kuchiki of the Saga Fruit Tree Experiment Station, Japan. The present work was supported in part by a Grant-in-Aid for Scientific Research (no. 21380039) from the Japan Society of the Promotion of Science.

Open Access This article is distributed under the terms of the Creative Commons Attribution Noncommercial License which permits any noncommercial use, distribution, and reproduction in any medium, provided the original author(s) and source are credited.

\section{References}

Barrion AT, Litsinger JA (1987) Strepsipteran parasites of rice leafhoppers and planthoppers in the Philippines. IRRN 12:37-38

Benrey B, Lamp WO (1994) Biological control in the management of planthopper populations. In: Denno RF, Perfect TJ (eds) Planthopper, their ecology and management. Chapman and Hall, New York, pp 519-550

Carcupino M, Kathirithamby J, Mazzini M (1998) Testis morphology and spermatogenesis in two species of Elenchus (Strepsiptera: Elenchidae). Int J Insect Morphol Embryol 27:9-19

Chalwatzis N, Baur A, Stetzer E, Kinzelbach R, Zimmermann FK (1995) Strongly expanded 18S rRNA genes correlated with a peculiar morphology in the insect order of Strepsiptera. Zoology 98:115-126

Chandra G (1978) Natural enemies of rice leafhoppers and planthoppers in the Philippines. IRRN 3:20-21

Chandra G (1980) Taxonomy and bionomics of the insect parasites of rice leafhoppers and planthoppers in the Philippines and their importance natural biological control. Philipp Entomol 4:119-139

Choe CP, Hwang UW, Kim W (1999) Putative secondary structures of unusually long strepsipteran SSU rRNAs and its phylogenetic implication. Mol Cells 9:191-199
Dover G (1982) Molecular drive: a cohesive mode of species evolution. Nature 299:111-117

Esaki T, Hashimoto S (1931) Report on the leaf-hoppers injurious to the rice plant and their natural enemies. Entomol Lab Dep Agric Kyushu Univ 2:1-59

Gillespie JJ, McKenna CH, Yoder MJ, Gutell RR, Johnston JS, Kathirithamby J, Cognato AI (2005) Assessing the odd secondary structural properties of nuclear small subunit ribosomal RNA sequences (18S) of the twisted-wing parasites. Insect Mol Biol 14:625-643

Halbert NR, Ross LD, Kathirithamby J, Woolley JB, Saff RR, Johnston JS (2001) Phylogenetic analysis as a means of species identification within Myrmecolacidae (Strepsiptera). Tijdschr Entomol 144:179-186

Hirao J, Ito K (1980) Observations on rice planthoppers collected over the East China Sea in June and July, 1974. Jpn J Appl Entomol Zool 24:121-124 (in Japanese, English summary)

Hirashima Y, Aizawa K, Miura T, Wongsiri T (1979) Field studies on the biological control of leafhoppers and planthoppers (Hemiptera: Homoptera) injurious to rice plants in south-east Asia. Progress report for the year 1977. ESAKIA 13:1-20

Kathirithamby J (1993) Descriptions of Strepsiptera (Insecta) from Southeast Asia, with a checklist of the genera and species occurring in the region. Raff Bull Zool 41:173-201

Kathirithamby J (2009) Host-parasitoid associations in Strepsiptera. Annu Rev Entomol 54:227-249

Kathirithamby J (2011) Partial list of Strepsiptera species. Tree of life web project: partial list of Strepsiptera species. http://tolweb.org/ notes/?note_id $=2978$

Kifune T (1986) A new host of Elenchus japonicus (Strepsiptera, Elenchidae) in Kyushu, Japan. Kontyu 54:525

Kifune T, Hirashima Y (1975) A new species of the genus Elenchus from Thailand (Strepsiptera: Elenchidae) (Notulae Strepsipterologicae II). Mushi 48:155-160

Kifune T, Maeta Y (1986) New host records of Elenchus japonicus (Esaki et Hashimoto, 1931) (Strepsiptera, Elenchidae) from Japan and the East China Sea. Kontyu 54:359-360

Kisimoto R (1976) Synoptic weather conditions inducing longdistance immigration of planthoppers, Sogatella furcifera Horváth and Nilaparvata lugens Stål. Ecol Entomol 1:95-109

Kitamura K, Nishikata Y (1987) A monitor-trap survey of parasitoids of the leaf- and planthoppers supposedly migrated from the mainland China (Homoptera: Auchenorrhyncha). Bull Fac Agric Shimane Univ 21:171-177 (in Japanese, English summary)

Maeta Y, Machita Y, Kitamura K (2007) Studies on the biology of Elenchus japonicus (Esaki et Hashimoto) (Strepsiptera, Elenchidae). Jpn J Entomol 10:33-46 (in Japanese, English summary)

Noda H (1986) Pre-mating flight of rice planthopper migrants (Homoptera: Delphacidae) collected on the East China Sea. Appl Entomol Zool 21:175-176

Noda H, Miyoshi T, Zhang Q, Watanabe K, Deng K, Hoshizaki S (2001) Wolbachia infection shared among planthoppers (Homoptera: Delphacidae) and their endoparasite (Strepsiptera: Elenchidae): a probable case of interspecies transmission. Mol Ecol 10:2101-2106

Otuka A, Matsumura M, Sanada-Morimura S, Takeuchi H, Watanabe T, Ohtsu R, Inoue H (2010) The 2008 overseas mass migration of small brown planthopper, Laodelphax striatellus, and subsequent outbreak of rice stripe disease in western Japan. Appl Entomol Zool 45:259-266

Pohl H, Beutel RG (2008) The evolution of Strepsiptera (Hexapoda). Zoology 111:318-338

Simon C, Frati F, Beckenbach A, Crespi B, Liu H, Flook P (1994) Evolution, weighting, and phylogenetic utility of mitochondrial gene sequences and a compilation of conserved polymerase chain reaction primers. Ann Entomol Soc Am 87:651-701 
Swofford DL (2002) PAUP*: phylogenetic analysis using parsimony (and other methods) 4.0 beta. Sinauer Associates, Sunderland

Tautz D, Hancock JM, Webb A, Tautz C, Dover GA (1988) Complete sequences of rRNA genes of Drosophila melanogaster. Mol Biol Evol 5:366-376

Thompson JD, Gibson TJ, Plewniak F, Jeanmougin F, Higgins DG (1997) The Clustal X window interface: flexible strategies for multiple sequence alignment aided by quality analysis tools. Nucleic Acids Res 22:4673-4680

White TJ, Btuns T, Lee S, Taylor J (1990) Amplification and direct sequencing of fungal ribosomal RNA genes for phylogenetics.
In: Innis MA, Gelfand DH, Sninsky JJ, White TJ (eds) PCR protocols: a guide to methods and applications. Academic Press, San Diego, pp 315-322

Whiting MF, Carpenter JC, Wheeler QD, Wheeler CH (1997) The strepsiptera problem: phylogeny of the holometabolous insect orders inferred from $18 \mathrm{~S}$ and $28 \mathrm{~S}$ ribosomal DNA sequences and morphology. Syst Biol 46:1-68

Yano K, Kifune T (1994) The occurrence of Elenchus japonicus (Esaki et Hashimoto) (Strepsiptera, Elenchidae) in Mindanao, the Philippines. Jpn J Entomol 62:595-596 